\title{
Effects of nutritional conditions on lipid production by cyanobacteria
}

\author{
RAQUEL S. CORDEIRO ${ }^{1}$, IZABELA C.D. VAZ ${ }^{1}$, SÉRGIA M.S. \\ MAGALHÃES ${ }^{2}$ and FRANCISCO A.R. BARBOSA ${ }^{1}$
${ }^{1}$ Laboratório de Limnologia, Ecotoxicologia e Ecologia Aquática, Instituto de Ciências Biológicas, Universidade Federal de Minas Gerais, Av. Antônio Carlos, 6627, 31270-901 Belo Horizonte, MG, Brazil
${ }^{2}$ Laboratório de Água, Departamento de Farmácia Social, Faculdade de Farmácia, Universidade Federal de Minas Gerais, Av. Antônio Carlos, 6627, Sala 1052, 31270-901 Belo Horizonte, MG, Brazil

Manuscript received on October 27, 2015; accepted for publication on March 18, 2016

\begin{abstract}
The present study evaluated the effects of the culturing media and the levels of nitrogen and phosphorus on the growth, biomass productivity and lipid production of four species of Microcystis (M. novacekii, M. aeruginosa, $M$ panniformis and $M$. protocystis). The lipid extract was obtained by refluxing with dichloromethane (Soxhlet). The biomass and biomass productivity yields were maximized with ASM1 medium treatment enriched with nitrogen and/or phosphorus $\left(0.25-0.65 \mathrm{~g} / \mathrm{L}\right.$ and $25-50.7 \mathrm{mg} / \mathrm{L} \mathrm{d}^{-1}$, respectively). The lipid extract yields from $M$. panniformis and $M$. novacekii were inversely correlated with the concentration of nitrogen and directly correlated with the concentration of phosphorus (35.8 $\%$ and $31.7 \%$ ). The lipid extract yield from M. aeruginosa was inversely correlated with the nutrient concentration (23.3\%). M. protocystis exhibited a higher lipid content in the control medium $(41.5 \%)$ than in the nitrogen-enriched media. The recorded results show that a nutrient-poor culture medium favours cell growth and stimulates lipid accumulation, which directly affects the cost of cultivation by reducing nutrient consumption. All studied species may serve as biomass sources for biodiesel production, although M. protocystis exhibited the highest lipid production. Further studies are necessary to determine the composition of the recorded lipid extract.
\end{abstract}

Key words: Biodiesel, culture media, lipid extraction, Microcystis, Nitrogen and phosphorus deprivation and Stress.

\section{INTRODUCTION}

The decrease of worldwide oil reserves combined with the increase in the emission of greenhouse gases due to the use of fossil fuels has become a major impetus for the search for more environmentally friendly resources in order to meet the world's

Correspondence to: Raquel Cordeiro

E-mail: raqquel.cordeiro@gmail.com energetic needs in a sustainable manner (Silva et al. 2014). To this end, biofuels originating from plant biomass are an appealing option, although the energy used for fertilization, plantation, irrigation, and harvesting (Vasudevan and Briggs 2008) decreases the attractiveness of their production from social, economic, and environmental points of view. 
Cyanobacteria are photosynthesizing, ancient and thriving microorganisms (gram-negative) (Gademann and Portmann 2008, Mukherjee et al. 2013). These organisms produce a vast array of metabolites, such as proteins, carbohydrates, carotenoids, vitamins and lipids, which can be used as food sources for humans and animals, in pharmaceutical and cosmetic products and to produce energy (Parmar et al. 2011, Kaiwan-arporn et al. 2012, Borowitzka and Moheimani 2013, George et al. 2014, Zeng et al. 2015).

Cyanobacteria are promising for the production of biofuels mainly due to their high reproduction rates, high photosynthetic capacity and low nutritional requirements. Furthermore, these organisms do not compete for fertile and arable lands, and the plasticity of their metabolism allows lipid biosynthesis to be guided under controlled conditions. Lastly, several cyanobacteria strains can be easily genetically manipulated (Xin et al. 2010, Sharma et al. 2011, Sarsekeyeva et al. 2015).

To serve as an alternative for biofuel production, cyanobacteria must exhibit high biomass productivity and high lipid yields (Pulz and Gross 2004, Silva et al. 2014). However, distinct factors, such as light intensity, temperature, $\mathrm{pH}$ and nutrient availability, can affect their growth, biomass productivity rates and lipid content (Mandal and Mallick 2009, Mata et al. 2010, Ahmad et al. 2011, Da Rós et al. 2012, George et al. 2014). Specifically, the concentrations of nitrogen and phosphorus within the culturing system are considered determinants of biomass growth and lipid accumulation (Xin et al. 2010, Markou et al. 2014).

Previous studies (e.g., Xin et al. 2010, Markou et al. 2012, Pancha et al. 2014) suggest that stress due to nutrient limitation can increase lipid content. The Redfield ratio proposed by Atkinson and Smith (1983) indicated that cyanobacteria cultivated with an $\mathrm{N}: \mathrm{P}>30: 1$ exhibit limited growth due to insufficient phosphorus levels, whereas an
$\mathrm{N}: \mathrm{P}<10: 1$ indicates nitrogen deficiency, which promotes growth. Thus, low N:P proportions were found to promote growth, which implies that the culture medium needs to be optimized to maximize product yields based on the developmental capacity of these microorganisms (George et al. 2014).

Several studies have indicated that nitrogen and phosphorus limitation increases the accumulation of lipids in microalgae (e.g., Li et al. 2008, Xin et al. 2010, Lin and Lin 2011, Da Rós et al. 2012, Markou and Nerantzis 2013, Mayers et al. 2014). However, several of these studies only focused on the growth and accumulation of lipids by microalgae, although cyanobacteria also alter their growth rate and cellular composition when cultivated under sub- or supra-optimal nutrient conditions to address difficulties imposed by new environmental conditions (Makareviciene et al. 2013).

The present study aimed to i) evaluate the growth of four species of cyanobacteria maintained in three distinct nutritional culture media in order to select the best medium for maximizing biomass production and ii) investigate the effects of the nitrogen and phosphorus concentrations on the growth and accumulation of lipids for biodiesel production.

\section{MATERIALS AND METHODS}

\section{CYANOBACTERIA}

The following species were used in the present study: Microcystis panniformis J. Komárek, J. Komárková-Legnerová, C.L. Sant'Anna, M.T.P. Azevedo, \& P.A.C. Senna, (2002), Microcystis aeruginosa (Kützing) Kützing (1846), Microcystis novacekii (Komárek) Compère (1974) and Microcystis protocystis Crow (1923). The cyanobacteria were cultured at the Laboratory of Limnology, Ecotoxicology and Aquatic Ecology - LIMNEA at the Federal University of Minas Gerais. These species were collected, identified and 
isolated from natural lakes of the Rio Doce State Park in the southeast of Brazil.

\section{CULTURE CONDITIONS}

The cyanobacteria were cultivated in the following liquid media: Artificial Seawater Medium modified (ASM-1) (Gorham et al. 1964), Blue-Green 11 (BG-11) (Allen and Stanier 1968, Rippka et al. 1979) and Bold's Basal Medium (BBM) (Bold 1949, Bischoff and Bold 1963). The chemical compositions of the media are shown in Figure 1. The experiments were conducted in triplicate in Erlenmeyer flasks containing $700 \mathrm{ml}$ of culture medium and $10 \%(\mathrm{v} / \mathrm{v})$ of inoculum. The flasks were kept under constant light (40 W fluorescent lights $\left./ 32 \mu \mathrm{mol} . \mathrm{m}^{-2} . \mathrm{s}^{-1}\right)$ at a temperature of $20{ }^{\circ} \mathrm{C} \pm$ 2 and bubbling with filtered air $\left(3.5 \mathrm{~L} \mathrm{~min}^{-1}\right)$ for 13 days. These conditions were determined based on preliminary tests.

CULTURE CONDITIONS UNDER DISTINCT NITROGEN AND PHOSPHORUS CONCENTRATIONS

The total nitrogen (N) and phosphorus (P) concentrations of ASM-1 medium were modified (Table I) according to Da Rós et al. (2012). The experiments were conducted for 13 days in Erlenmeyer flasks containing $150 \mathrm{ml}$ of ASM1 modified medium and $10 \%(\mathrm{v} / \mathrm{v})$ of inoculum. The treatments were conducted under the same conditions described above. All experiments were conducted in triplicate and repeated 3 times.

\section{GROWTH CURVES}

The growth of each species was determined via optical density measurements (UV 1700 PhamaSpec SHIMADZU), namely the $\mathrm{OD}_{655}$ (M. panniformis), $\mathrm{OD}_{700}$ (M. aeruginosa), $\mathrm{OD}_{680}$ (M. novacekii), and $\mathrm{OD}_{700}$ (M. protocystis). The biomass concentration was determined based on individual calibration curves of optical density as a function of dry weight for each culture and used to calculate dry weight

\begin{tabular}{|c|c|c|c|}
\hline Composition & $\begin{array}{l}\text { ASM-1 } \\
(\mathrm{mg} / \mathrm{L})\end{array}$ & $\begin{array}{c}\text { BG-11 } \\
\text { (mg/L) }\end{array}$ & $\begin{array}{c}\text { BBM } \\
(\mathrm{mg} / \mathrm{L})\end{array}$ \\
\hline Total Nitrogen & 28 & 247.4 & 41.2 \\
\hline Total Phosphorus & 2.3 & 4.2 & 13 \\
\hline $\mathrm{N}: \mathrm{P}$ Ratio & $12: 1$ & $59: 1$ & $3: 1$ \\
\hline $\mathrm{NaCl}$ & ----- & ---- & 25 \\
\hline $\mathrm{NaNO}_{3}$ & 170 & 1500 & 250 \\
\hline $\mathrm{CaCl}_{2} \cdot 2 \mathrm{H}_{2} \mathrm{O}$ & 29 & 36 & 25 \\
\hline $\mathrm{MgCl}_{2} \cdot 6 \mathrm{H}_{2} \mathrm{O}$ & 41 & ----- & ----- \\
\hline $\mathrm{MgSO}_{4} \cdot 7 \mathrm{H}_{2} \mathrm{O}$ & 49 & 75 & 75 \\
\hline $\mathrm{H}_{2} \mathrm{SO}_{4}$ & ---- & ---- & ---- \\
\hline $\mathrm{K}_{2} \mathrm{HPO}_{4}$ & 8.7 & 30.6 & 75 \\
\hline $\mathrm{KH}_{2} \mathrm{PO}_{4}$ & ----- & ----- & 175 \\
\hline $\mathrm{Na}_{2} \mathrm{HPO}_{4} \cdot 12 \mathrm{H}_{2} \mathrm{O}$ & 17.8 & ----- & ----- \\
\hline $\mathrm{Na}_{2} \mathrm{Mg}$ EDTA & ----- & 1 & ----- \\
\hline $\mathrm{NaCO}_{3}$ & ----- & 20 & ----- \\
\hline $\mathrm{CuSO}_{4} \cdot 5 \mathrm{H}_{2} \mathrm{O}$ & ---- & 0.08 & 0.08 \\
\hline $\mathrm{Co}\left(\mathrm{NO}_{3}\right) 2.6 \mathrm{H}_{2} \mathrm{O}$ & ----- & ----- & 0.05 \\
\hline $\mathrm{CoCl}_{2} \cdot 6 \mathrm{H}_{2} \mathrm{O}$ & 0.0095 & 0.50 & ----- \\
\hline $\mathrm{CuCl}_{2} \cdot 2 \mathrm{H}_{2} \mathrm{O}$ & 0.00065 & ----- & ----- \\
\hline $\mathrm{MnCl}_{2} \cdot 4 \mathrm{H}_{2} \mathrm{O}$ & 0.70 & 1.81 & 1.81 \\
\hline $\mathrm{NaMoO}_{4} \cdot 2 \mathrm{H}_{2} \mathrm{O}$ & ----- & 0.02 & 0.39 \\
\hline $\mathrm{ZnSO}_{4} \cdot 7 \mathrm{H}_{2} \mathrm{O}$ & 0.35 & 0.22 & 0.22 \\
\hline $\begin{array}{l}\text { Citric Acid } \\
\text { Monohydrate }\end{array}$ & ----- & 6 & ----- \\
\hline $\mathrm{C}_{6} \mathrm{H}_{11} \mathrm{FeNO}_{7}$ & ----- & 6 & ----- \\
\hline $\mathrm{H}_{3} \mathrm{BO}_{3}$ & 1.24 & 2.86 & 10.91 \\
\hline $\mathrm{FeCl}_{3} \cdot 6 \mathrm{H}_{2} \mathrm{O}$ & 0.54 & ----- & ----- \\
\hline $\mathrm{FeSO}_{4} \cdot 7 \mathrm{H}_{2} \mathrm{O}$ & ----- & ----- & 4.98 \\
\hline EDTA $\mathrm{Na}_{2}$ & 3.72 & ----- & 10 \\
\hline $\mathrm{KOH}$ & ----- & ----- & 6.20 \\
\hline
\end{tabular}

Figure 1 - Composition of the culture media ASM-1, BG-11 and BBM.

TABLE I

Changes in nitrogen and phosphorus concentrations of the ASM-1 culture medium.

\begin{tabular}{cccc}
\hline Treatment & $\begin{array}{c}\text { Total } \\
\text { Nitrogen } \\
(\mathbf{m g} / \mathbf{L})\end{array}$ & $\begin{array}{c}\text { Total } \\
\text { Phosphorus } \\
(\mathbf{m g} / \mathbf{L})\end{array}$ & N:P Ratio \\
\hline $1^{*}$ & 28 & 2.3 & $12: 1$ \\
2 & 42 & 3.5 & $12: 1$ \\
3 & 14 & 3.5 & $4: 1$ \\
4 & 42 & 1.2 & $35: 1$ \\
5 & 14 & 1.2 & $11: 1$ \\
\hline
\end{tabular}

*Quantity according to ASM-1 standard culture medium. 
from optical density. The average dry weight of the samples was used to generate growth curves. Samples were collected at 48-hour intervals, and the maximum biomass production and biomass productivity were determined based on the growth curves. Specifically, the biomass productivity (Px) was determined using Equation 1:

$\mathrm{Px}=\Delta \mathrm{X} / \Delta \mathrm{t}$

\section{HARVESTING AND BIOMASS DRYNESS}

Cyanobacteria were harvested via centrifugation at $8000 \mathrm{x} \mathrm{g}$ and $4{ }^{\circ} \mathrm{C}$ for $10 \mathrm{~min}$. The recovered biomass was dried in a convection oven at $50{ }^{\circ} \mathrm{C}$ for $24 \mathrm{~h}$. The dry biomass was determined based on the gravimetric difference.

\section{LIPID FRACTION EXTRACTION}

The Soxhlet method with dichloromethane reflux was used to extract lipids because it was shown to be more efficient in preliminary tests. After 4 h. of extraction, the crude organic extract was removed and concentrated under a vacuum in a rotary evaporator (Marconi model TE-120) at temperatures up to $40{ }^{\circ} \mathrm{C}$. The samples were then transferred to a convection oven and dried at 40 ${ }^{\circ} \mathrm{C}$ until reaching a constant weight. The lipid yield was calculated by dividing the lipid extract weight (g) by the dry biomass ( $\mathrm{g}$ ) and multiplying the result by 100 .

\section{STATISTICAL ANALYSIS}

The results are expressed as the mean $\pm \mathrm{SD}$ (Standard Deviation). The effect of the culture medium on the biomass was tested with an analysis of variance (ANOVA, factor $=$ culture media, days $=$ repeated measurements) over all collected days. The effect of the culture media and distinct nitrogen and phosphorus treatments on the biomass concentration, biomass productivity and lipid content was tested with a one-way ANOVA.
The normality of the data was analysed using the Shapiro-Wilk test, whereas homoscedasticity was assessed using Levene's test. To assess the significance of differences ( $p<0.05)$, the mean were compared with a post hoc analysis (Tukey's LSD) using STATISTICA software, version 10.

\section{RESULTS}

The cyanobacteria growth curves recorded for the three culture media are shown in Figure 2. Significant effects on the biomass concentrations of all studied species were observed $(\mathrm{P}=0.000)$. Specifically, the following maximum biomass levels were obtained using ASM-1 medium: $M$. protocystis $(0.887 \mathrm{~g} / \mathrm{L})$, M. panniformis $(0.626$ $\mathrm{g} / \mathrm{L}), M$. aeruginosa $(0.504 \mathrm{~g} / \mathrm{L})$ and $M$. novacekii $(0.484 \mathrm{~g} / \mathrm{L})$.

The mean biomass productivity values are shown in Figure 3. Significant effects of the tested media were recorded for all evaluated species $(\mathrm{P}=$ 0.000 ). The biomass productivity rate was higher for strains that were cultivated in the ASM-1 medium than those in all other media tested. The highest productivity was obtained for $M$. protocystis $(77.8$ $\pm 4.8 \mathrm{mg} / \mathrm{L} \mathrm{d}^{-1}$ ), followed by M. panniformis (56 \pm $\left.2.9 \mathrm{mg} / \mathrm{L} \mathrm{d}^{-1}\right)$, M. aeruginosa $\left(46.4 \pm 2.2 \mathrm{mg} / \mathrm{L} \mathrm{d}^{-1}\right)$ and $M$. novacekii $\left(41.5 \pm 3.4 \mathrm{mg} / \mathrm{L} \mathrm{d}^{-1}\right)$.

Based on the above results, the ASM-1 medium was selected to evaluate the effect of the $\mathrm{N}$ and $\mathrm{P}$ concentrations on the maximum biomass concentration, productivity, and lipid accumulation by cyanobacteria.

The effects of the $\mathrm{N}$ and $\mathrm{P}$ concentrations on the biomass production are presented in Figure 4. Specifically, the $\mathrm{N}$ and $\mathrm{P}$ concentrations did not significantly affect the biomass production by $M$. aeruginosa and $M$. protocystis but did significantly affect the biomass production by $M$. panniformis $(\mathrm{P}=0.000)$ and $M$. novacekii $(\mathrm{P}=0.001)$. Among the studied species, $M$. protocystis produced the most biomass in all tested treatments ( 0.52 to 0.61 

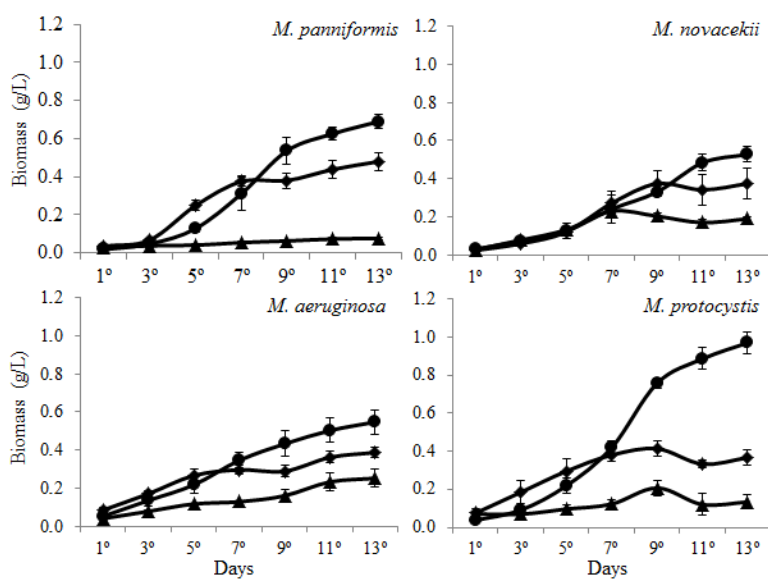

Figure 2 - Growth curves and standard deviations for cyanobacteria species in distinct culture media for 13 days: $(\bullet)$ ASM-1, ( ) BG-11 and ( $\mathbf{\Delta})$ BBM.

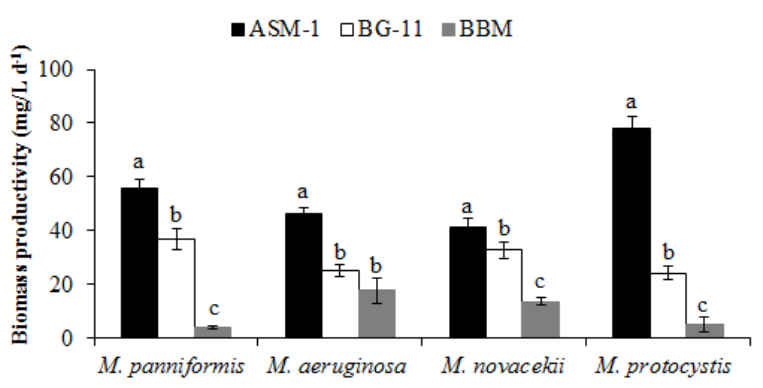

Figure 3 - Mean biomass productivity and standard deviations $\left(\mathrm{mg} / \mathrm{L} \mathrm{d}^{-1}\right)$ of cyanobacteria species cultivated in distinct culture media for 13 days. *Significant differences among the culture media are indicated by different letters (ANOVA OneWay with post hoc Tukey's LSD, $\mathrm{p}<0.05$ ).

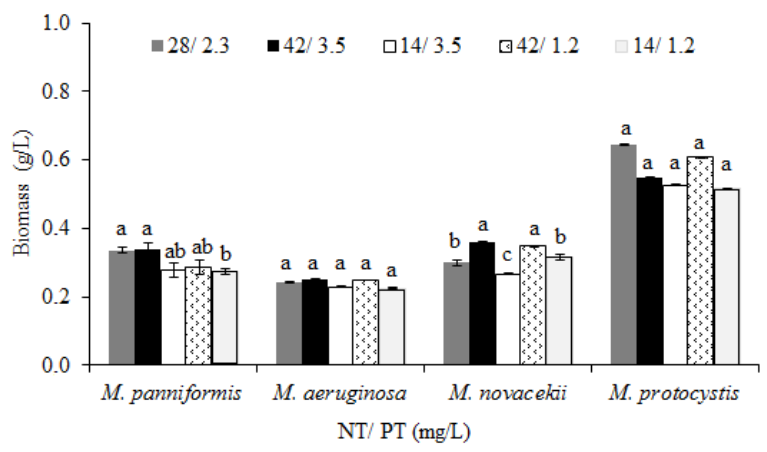

Figure 4 - Maximum biomass and standard deviations (g/L) for the cyanobacteria species cultivated at distinct nitrogen and phosphorous concentrations for 13 days. Significant differences between treatments are represented by different letters (ANOVA One-Way with post hoc Tukey's LSD, $\mathrm{p}<0.05)$. $\mathrm{g} / \mathrm{L}$ ), whereas the other species produced more biomass in treatment which included increased $\mathrm{N}$ and $\mathrm{P}$ concentrations. Specifically, the maximum amounts of biomass produced were $0.36 \pm 1.8 \mathrm{~g} / \mathrm{L}$ for $M$. novacekii, $0.34 \pm 0.9 \mathrm{~g} / \mathrm{L}$ for $M$. panniformis and $0.25 \pm 2.7 \mathrm{~g} / \mathrm{L}$ for M. aeruginosa.

The effects of the $\mathrm{N}$ and $\mathrm{P}$ concentrations on the biomass productivity rates and lipid yields of distinct species are shown in Figure 5. The treatments significantly affected the productivity rates of all tested species $(\mathrm{P}=0.000)$, except for $M$. aeruginosa. The biomass productivity of $M$. protocystis $\left(50.7 \pm 1.3 \mathrm{mg} / \mathrm{L} \mathrm{d}^{-1}\right)$ was maximized in the treatment which was only enriched with nitrogen. The productivity of $M$. panniformis was maximized in the control $\left(33.4 \pm 1.0 \mathrm{mg} / \mathrm{L} \mathrm{d}^{-1}\right)$, whereas those of $M$. novacekii and $M$. aeruginosa were maximized in the treatment which included higher concentrations of nitrogen and phosphorus ( $32.5 \pm 0.5$ and $24 \pm 0.26 \mathrm{mg} / \mathrm{L} \mathrm{d}^{-1}$, respectively).

The lipid content extracted from cyanobacteria is shown in Figure 5. The treatments significantly affected the lipid content of all tested species $(\mathrm{P}=$ 0.000), except for $M$. aeruginosa. $M$. panniformis and $M$. novacekii produced greater amounts of lipid in response to lower nitrogen and higher $\mathrm{P}$ concentrations $(35.8 \pm 2$ and $31.7 \pm 1.3 \%$, respectively), which yielded the maximum lipid levels, followed by treatment which included lower $\mathrm{N}$ and $\mathrm{P}$ concentrations $(34.8 \pm 1$ and $30 \pm 1 \%$, respectively). The nitrogen concentrations were limited in these two treatments. M. aeruginosa exhibited higher lipid values when cultivated at low $\mathrm{N}$ and $\mathrm{P}$ concentrations. However, as shown in Figure 5, the lipid fraction obtained from this species does not depend on the nitrogen and phosphorus concentrations because the recorded mean are similar among treatments, ranging from $20.5 \pm 1.7$ to $23.1 \pm 1.1 \%$. The behaviour of $M$. protocystis differed from that of other species. Treatment which is rich in nitrogen but poor in phosphorus maximized the lipid fraction $(40.5 \pm$ 


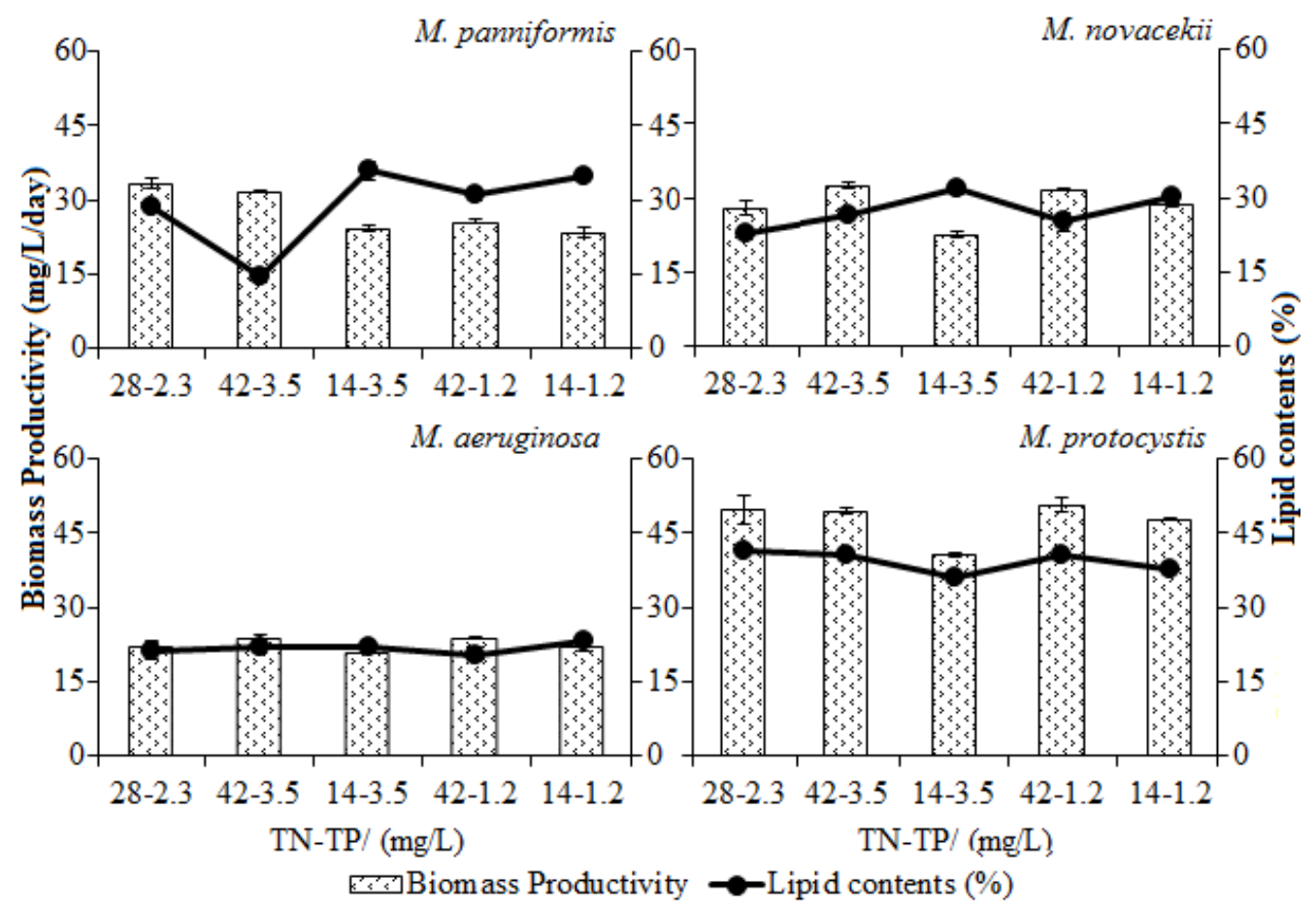

Figure 5 - Effect of the nitrogen and phosphorous concentrations on the average biomass productivity and lipid content (\%) of cyanobacteria for 13 days; standard deviations are also shown.

$0.2 \%)$. In this treatment the $\mathrm{N}: \mathrm{P}$ ratio is $35: 1$; thus, the phosphorus concentration is strongly limited. Nevertheless, similar lipid fractions $(40.4 \pm 0.6$ and $40.1 \pm 2.2 \%$, respectively), were recorded for the control and treatment which included higher concentrations of nitrogen and phosphorus, which both feature an N:P ratio of 12:1 whereas lower values were recorded for treatments which feature reduced nitrogen levels (11:1 and 4:1, respectively).

\section{DISCUSSION}

The culture media significantly affected the growth of Microcystis species under test conditions. Moreover, the changes in the nitrogen and phosphorus contents in the ASM-1 medium significantly affected the growth, productivity and lipid yield.

BG-11, BBM and ASM-1 media are widely used to cultivate cyanobacteria. Their chemical composition is similar, particularly with respect to the nutrients included in the medium, although their concentrations differ among media. BG-11 and BBM contain higher levels of sulphates, nitrates and phosphates than ASM-1. Moreover, their $\mathrm{N}: \mathrm{P}$ ratios differ. Specifically, the BBM medium features an N:P ratio of $3: 1$, which resulted in clear reductions in growth that are likely due to the limited $\mathrm{N}$ concentration. This finding corroborates those of Nascimento and Azevedo (1999), who cultivated $S$. aquatilis $f$. salina at an $\mathrm{N}: \mathrm{P}$ ratio of $3: 1$ and recorded a low growth rate and biomass accumulation. This result is also similar to those obtained by George et al. (2014), who reported that the microalgae Ankistrodesmus falcatus exhibited reduced growth in BBM medium due to the low nitrogen concentration. The nitrogen concentration in the BG-11 medium is not limited (59:1) and consequently did not significantly affect the growth of microalgae, although this medium was not as effective as the ASM-1 medium (12:1). 
Although high nutrient concentrations, particularly of nitrogen and phosphorus, are accepted to favour the growth of cyanobacteria (Ernst et al. 2005), some studies recommend that these microorganisms must be treated individually and not as an homogeneous group because each species responds differently to the nutritional conditions (Marinho and Azevedo 2007, Markou and Georgakakis 2011, Loza et al. 2014). Our findings corroborate these previous findings.

Moreover, our findings are also corroborated by those of Shen and Song (2007), who studied different phenotypes of Microcystis (colonial and unicellular). They found that low phosphorous concentrations maximized the performance of colonial lineages compared with the unicellular forms. This effect can be attributed to the presence of mucilage in the colonial forms, which play an important role in the sequestration and assimilation of nutrients. Moreover, Loza et al. (2004) verified that high nutrient concentrations favoured some of the four studied cyanobacteria species (filamentous and colonials), whereas others produced higher yields in response to low concentrations due to their ecophysiological characteristics, such as the presence of heterocysts, which allow nitrogen fixation - an essential process during periods of nitrogen deprivation.

Finally, Vézie et al. (2002) verified that strains of toxic Microcystis performed better than nontoxic strains when cultivated under high nitrogen and phosphorus concentrations. In our study, this relationship with toxicity was not observed. The non-toxic species $M$. protocystis and M. novacekii performed better at higher concentrations of $\mathrm{N}$ and $\mathrm{P}$ than the toxic species $M$. aeruginosa and $M$. panniformis.

The results from our first phase show that the ASM-1 medium, whose composition is simpler than those of the BG-11 and BBM media, increased the productivity of the evaluated species. High biomass productivity rates are fundamental in large-scale cultivation processes, such as the production of biofuels, because high biomass densities increase the yield per volume of harvest while decreasing the cultivation costs (Griffiths and Harrison 2009). Thus, a low-cost culture medium associated with rapid growth is attractive for biotechnological applications.

The biomass productivity and the lipid content are among the major parameters affecting the economic viability of biodiesel production from oils extracted from microalgae and cyanobacteria (Li et al. 2008, Dhup and Dhawan 2014). However, these parameters are not necessarily correlated. In response to nutrient scarcity, the metabolism of microalgae and cyanobacteria has been shown to be directed towards the synthesis of reserve compounds, such as saturated fatty acids, while halting cell division and consequently reducing growth rates (Alonso et al. 2000, Xin et al. 2010). According to Xin et al. (2010), nutritional limitations may result in lipid accumulation due to the following changes: a decrease in the thylakoid membrane content of the cell or the activation of acyl hydrolase and stimulation of phospholipid hydrolysis, which can enhance the intracellular fatty acid content.

In the present study, this relationship was observed for $M$. panniformis, $M$. aeruginosa and $M$. novacekii; specifically, the nitrogen and/ or phosphorus concentrations were inversely correlated with lipid accumulation and directly correlated with biomass. Similar results were recorded by Converti et al. (2009) for the microalgae Nannochloropsis oculata and Chlorella vulgaris. Specifically, nitrogen reduction doubled the accumulation of lipids while reducing the biomasses and productivity of both species. In a study of Scenedesmus sp., Xin et al. (2010) recorded high lipid contents in response to $\mathrm{N}$ and $\mathrm{P}$ limitation, followed by a reduction in the productivity rate. Rios et al. (2015) studied the microalga Desmodesmus sp. and recorded an increase in the lipid content 
followed by a reduction of biomass in response to nitrogen limitation. However, this relationship was not observed for $M$. protocystis, whose productivity and lipid production were directly correlated with the nitrogen availability.

The majority of studies of the effects of $\mathrm{N}$ and $\mathrm{P}$ limitation on growth and lipid accumulation have focused on microalgae. However, Da Rós et al. (2012) examined M. aeruginosa and observed high productivity values in response to treatment with high $\mathrm{N}$ levels $\left(83 \mathrm{mg} / \mathrm{L} \mathrm{day}^{-1}\right)$, whereas the highest lipid content was recorded with standard ASM1 medium. In our study, the species responses, particularly those of $M$. aeruginosa, were distinct, but the productivity rates were generally directly correlated with the $\mathrm{N}$ and $\mathrm{P}$ concentrations whereas the lipid concentration was inversely correlated with the nitrogen level. Moreover, the other Microcystis species in this study produced more lipids than those reported by the aforementioned authors.

Several other authors have also reported an inverse correlation between the lipid and nutrient contents for cyanobacteria species, such as Spirulina sp., which triple their lipid content in response to low nitrogen availability (Macedo and Alegre 2001), and for microalgae, such as Monoraphidium sp. (Dhup and Dhawan 2014), Chlorella pyrenoidosa (Nigam et al. 2011) and Neochloris oleoabundans ( $\mathrm{Li}$ et al. 2008).

Overall, cyanobacteria produce oil yields ranging from 5 to $37 \%$. Sharathchandra and Rajashekhar (2011) evaluated 13 species of cyanobacteria from distinct aquatic environments and recorded lipid production rates ranging from 10.5 to $28.2 \%$, with the maximum value being produced by $M$. aeruginosa (28.2 \%), whereas Da Rós et al. (2013) also reported a lipid yield of $28 \%$ for this species, Synechococcus sp. and Trichormus sp. also produced yields of 26.9 and $23.7 \%$, respectively.
The comparison of lipid production by microalgae and cyanobacteria is limited by the lack of standardization for lipid extraction procedures, which results in considerable variations among the obtained results. For example, Kaiwan-arporn et al. (2012) used distinct methods to extract lipids from Synechocystis aquatilis and recorded lipid contents between 6.5 and $21.3 \%$. Conversely, Silva et al. (2014) reported lipid contents of 13-36.8\% for Synechococcus sp., depending on the method of extraction, whereas Ashokkumar et al. (2014) used various solvents to extract oil from $M$. aeruginosa and obtained yields between 10.7 and $21.3 \%$.

In the present study, the lipid production by all Microcystis species ranged from 14.3 to $40.5 \%$. These rates are similar to or exceed the previously recorded rates for related species, which indicates that cyanobacteria constitute a new source of raw material for biofuel production under the tested conditions.

\section{CONCLUSIONS}

The present study elucidated new alternative sources of fuels by demonstrating that cyanobacteria species can constitute a low-cost raw material that produces favourable lipid yields for biofuel production. The low nutritional requirements of the tested species constitute an important point to be considered. Specifically, a culture medium poor in nutrients was shown to favour cell growth and stimulate the accumulation of lipids, which directly impacts the cost of cultivation by reducing nutrient utilization. Moreover, Microcystis species, which inhabit almost all types of aquatic ecosystems and very often dominate impacted environments worldwide easily adapted to laboratory conditions, which suggests that these species may be used in production plants. Among the studied species, $M$. protocystis produced the highest level of lipids, making it the most promising species for utilization at an industrial scale. New studies are necessary 
to determine the composition of the obtained lipid extract and to chemically and physically characterize these lipids for the production of biofuel.

\section{ACKNOWLEDGMENTS}

The authors thank the Conselho Nacional de Desenvolvimento Científico e Tecnológico (CNPqProcesso 471757/2013-6) and the Fundação de Amparo à Pesquisa do Estado de Minas Gerais (FAPEMIG- Processo APQ 01389-13) for the financial support and scholarship.

\section{REFERENCES}

AHMAD AL, YASIN NH, DEREK CJC AND LIM JK. 2011. Microalgae as a sustainable energy source for biodiesel production: a review. Renew Sust Energ Rev 15(1): 584593.

ALLEN MM AND STANIER RY. 1968. Selective isolation of blue-green algae from water and soil. J Gen Microbiol 51: 203-209.

ALONSO DL, BELARBI EH, FERNÁNDEZ-SEVILLA JM, RODRÍGUEZ-RUIZ J AND GRIMA EM. 2000. Acyl lipid composition variation related to culture age and nitrogen concentration in continuous culture of the microalga Phaeodactylum tricornutum. Phytochemistry 54(5): 461-471.

ASHOKKUMAR V, AGILA E, SALAM Z, PONRAJ M, DIN MFM AND ANI FN. 2014. A study on large scale cultivation of Microcystis aeruginosa under open raceway pond at semi-continuous mode for biodiesel production. Bioresource Technol 172: 186-193.

ATKINSON MJ AND SMITH SV. 1983. C:N:P ratios of benthic marine plants. Limnol Oceanogr 28: 568-574.

BISCHOFF HW AND BOLD HC. 1963. Phycological studies. IV. Some soil algae from Enchanted Rock and related algal species. University of Texas Publications 6318: 1-95. Andersen RA (Ed) (2005): Algal culturing techniques, 578 p., Elsevier Academic Press, London.

BOLD HC. 1949. The morphology of Chlamydomonas chlamydogama sp. nov. B Torrey Bot Club 76: 101-108.

BOROWITZKA MA AND MOHEIMANI NR. 2013. Sustainable biofuels from algae. Mitigation Adapt Strateg Glob Chang 18(1): 13-25.

COMPÈRE P. 1974. Algues de la région du lac Tchad. II. Cyanophycées. Cah. O.R.S.T.O.M. Sér Hydrobiol 8: 165198.

CONVERTI A, CASAZZA AA, ORTIZ EY, PEREGO P AND DEL BORGHI M. 2009. Effect of temperature and nitrogen concentration on the growth and lipid content of Nannochloropsis oculata and Chlorella vulgaris for biodiesel production. Chem Eng Process 48: 1146-1151.

CROW WB. 1923. The Taxonomy and Variation of the genus Microcystis in Ceylon. New Phytol 22: 59-68.

DA RÓS PCM, SILVA ME, SILVA-STENICO MFF AND DE CASTRO HF. 2012. Microcystis aeruginosa lipids as feedstock for biodiesel synthesis by enzymatic route. $\mathrm{J}$ Mol Catal 84: 177-182.

DA RÓS PCM, SILVA CSP, SILVA-STENICO ME, FIORE MF AND DE CASTRO HF. 2013. Assessment of chemical and physico-chemical properties of cyanobacterial lipids for biodiesel production. Mar Drugs 11(7): 2365-2381.

DHUP S AND DHAWAN V. 2014. Effect of nitrogen concentration on lipid productivity and fatty acid composition of Monoraphidium sp. Bioresource Technol 152: $572-575$.

ERNST A, DEICHER M, HERMAN PM AND WOLLENZIEN UI. 2005. Nitrate and phosphate affect cultivability of cyanobacteria from environments with low nutrient levels. Appl Environ Microb 71(6): 3379-3383.

GADEMANN K AND PORTMANN C. 2008. Secondary metabolites from cyanobacteria: complex structures and powerful bioactivities. Curr Org Chem 12(4): 326-341.

GEORGE B, PANCHA I, DESAI C, CHOKSHI K, PALIWAL C, GHOSH T AND MISHRA S. 2014. Effects of different media composition, light intensity and photoperiod on morphology and physiology of freshwater microalgae Ankistrodesmus falcatus - A potential strain for bio-fuel production. Bioresource Technol 171: 367-374.

GORHAM PR, MCLACHLAN J, HAMMER UT AND KIM WK. 1964. Isolation and culture of toxic strains of Anabaena flos-aquae (Lyngb.) de Bréb. Verh Internat Verein Limnol 15: 796-804.

GRIFFITHS MJ AND HARRISON STL. 2009. Lipid productivity as a key characteristic for choosing algal species for biodiesel production. J Appl Phycol 21(5): 493-507.

KAIWAN-ARPORN P, HAI PD, NGUYEN TT AND ANNACHHATRE AP. 2012. Cultivation of cyanobacteria for extraction of lipids. Biomass Bioenerg 44: 142-149.

KOMÁREK J, KOMÁRKOVÁ-LEGNEROVÁ J, SANT'ANNA CL, AZEVEDO MTD AND SENNA PAC. 2002. Two common Microcystis species (Chroococcales, Cyanobacteria) from tropical America, including $M$. panniformis sp. Cryptogamie Algol 23: 159-177.

LI Y, HORSMAN M, WANG B, WU N AND LAN CQ. 2008. Effects of nitrogen sources on cell growth and lipid accumulation of green alga Neochloris oleoabundans. Appl Microbiol Biotechnol 81(4): 629-636.

LIN Q AND LIN J. 2011. Effects of nitrogen source and concentration on biomass and oil production of a 
Scenedesmus rubescens like microalga. Bioresource Technol 102: 1615-1621.

LOZA V, PERONA E AND MATEO P. 2014. Specific responses to nitrogen and phosphorus enrichment in cyanobacteria: Factors influencing changes in species dominance along eutrophic gradients. Water Res 48: 622631.

MACEDO RT AND ALEGRE RM. 2001. Influência do teor de nitrogênio no cultivo de Spirulina maxima em dois níveis de temperatura - Parte II: Produção de lipídios. Ciênc Tecnol Aliment 21(2): 183-186.

MAKAREVICIENE V, SKORUPSKAITE V AND ANDRULEVICIUTE V. 2013. Biodiesel fuel from microalgae-promising alternative fuel for the future: a review. Rev Environ Sci Biotechnol 2: 119-130.

MANDAL S AND MALLICK N. 2009. Microalga Scenedesmus obliquus as a potential source for biodiesel production. Appl Microbiol Biot 84(2): 281-291.

MARINHO MM AND AZEVEDO SMFO. 2007. Influence of N/P ratio on competitive abilities for nitrogen and phosphorus by Microcystis aeruginosa and Aulacoseira distans. Aquat Ecol 41: 525-533.

MARKOU G, ANGELIDAKI I AND GEORGAKAKIS D. 2012. Microalgal carbohydrates: an overview of the factors influencing carbohydrates production, and of main bioconversion technologies for production of biofuels. Appl Microbiol Biot 96: 631-645.

MARKOU G AND GEORGAKAKIS D. 2011. Cultivation of filamentous cyanobacteria (blue-green algae) in agro-industrial wastes and wastewaters: a review. Appl Energ 88(10): 3389-3401.

MARKOU GAND NERANTZIS E. 2013. Microalgae for highvalue compounds and biofuels production: a review with focus on cultivation under stress conditions. Biotechnol Adv 31(8): 1532-1542.

MARKOU G, VANDAMME D AND MUYLAERT K. 2014. Microalgal and cyanobacterial cultivation: The supply of nutrientes. Water Res 65: 186-202.

MATA TM, MARTINS AA AND CAETANO NS. 2010. Microalgae for biodiesel production and other applications: A review. Renew Sust Energ Rev 14(1): 217-232.

MAYERS JJ, FLYNN KJ AND SHIELDS RJ. 2014. Influence of the N: P supply ratio on biomass productivity and time-resolved changes in elemental and bulk biochemical composition of Nannochloropsis sp. Bioresource Technol 169: 588-595.

MUKHERJEE G, NAYAK BK AND DAS D. 2013. Cyanobacteria as a valuable source of antiviral, antibacterial and antifungal compounds-an overview. Algol Stud 143(1): 3-25.

NASCIMENTO SM AND AZEVEDO SMFO. 1999. Changes in cellular components in a cyanobacterium (Synechocystis aquatilis $\mathrm{f}$. salina) subjected to different N/P ratios-an ecophysiological study. Environ Toxicol 14: 37-44.

NIGAM S, RAI MP AND RUPALI S. 2011. Effect of Nitrogen on Growth and Lipid Content of Chlorella pyrenoidosa. Am J Biochem Biotechnol 7(3): 124-129.

PANCHA I, CHOKSHI K, GEORGE B, GHOSH T, PALIWAL C, MAURYA R AND MISHRA S. 2014. Nitrogen stress triggered biochemical and morphological changes in themicroalgae Scenedesmus sp. CCNM 1077. Bioresour Technol 156: 146-154.

PARMAR A, SINGH NK, PANDEY A, GNANSOUNOU E AND MADAMWAR D. 2011. Cyanobacteria and microalgae: A positive prospect for biofuels. Bioresour Technol 102: 10163-10172.

PULZ O AND GROSS W. 2004. Valuable products from biotechnology of microalgae. Appl Microbiol Biot 65: 635-648.

RIOS LF, KLEIN BC, LUZ JR LF, MACIEL FILHO R AND WOLF MACIEL MR. 2015. Nitrogen Starvation for Lipid Accumulation in the Microalga Species Desmodesmus sp. Appl Biochem Biotech 175: 469-476.

RIPPKA R, DERUELLES J, WATERBURY JW, HERMAN M AND STANIER RY. 1979. Generic assignments, strain histories and properties of pure cultures of cyanobacteria. J Gen Microbiol 111: 1-61.

SARSEKEYEVA F, ZAYADAN BK, USSERBAEVA A, BEDBENOV VS, SINETOVA MA AND LOS DA. 2015. Cyanofuels: biofuels from cyanobacteria. Reality and perspectives. Photosynth Res 125: 329-340.

SHARATHCHANDRA K AND RAJASHEKHAR M. 2011. Total lipid and fatty acid composition in some freshwater cyanobacteria. J Algal Biomass Utln 2(2): 83-97.

SHARMA YC, SINGH B AND KORSTAD J. 2011. A critical review on recent methods used for economically viable and eco-friendly development of microalgae as a potential feedstock for synthesis of biodiesel. Green Chem 13: 2993-3006

SHEN H AND SONG L. 2007. Comparative studies on physiological responses to phosphorus in two phenotypes of bloom-forming Microcystis. Hydrobiologia 592(1): 475-486.

SILVA CSP, SILVA-STENICO ME, FIORE MF, DE CASTRO HF AND DA RÓS PCM. 2014. Optimization of the cultivation conditions for Synechococcus sp. PCC7942 (cyanobacterium) to be used as feedstock for biodiesel production. Algal Research 3: 1-7.

VASUDEVAN PT AND BRIGGS M. 2008. Biodiesel production-current state of the art and challenges. J Ind Microbiol Biotechnol 35: 421-430.

VÉZIE C, RAPALA J, VAITOMAA J, SEITSONEN J AND SIVONEN K. 2002. Effect of nitrogen and phosphorus on growth of toxic and nontoxic Microcystis strains and 
on intracellular microcystin concentrations. Microb Ecol 43(4): 443-454.

XIN L, HONG-YING H, KE G AND YING-XUE S. 2010. Effects of different nitrogen and phosphorus concentrations on the growth, nutrient uptake, and lipid accumulation of a freshwater microalga Scenedesmus sp. Bioresour Technol 101(14): 5494-5500.

ZENG Y, TANG J, LIAN S, TONG D AND HU C. 2015. Study on the conversion of cyanobacteria of Taihu Lake water blooms to biofuels. Biomass Bioenerg 73: 95-101. 